\title{
The past, present, and future of soils and human health studies
}

\author{
E. C. Brevik ${ }^{1}$ and T. J. Sauer ${ }^{2}$ \\ ${ }^{1}$ Department of Natural Sciences, Dickinson State University, Dickinson, ND 58601, USA \\ ${ }^{2}$ UDSA-ARS, National Laboratory for Agriculture and the Environment, Ames, IA, USA \\ Correspondence to: E. C. Brevik (eric.brevik@dickinsonstate.edu)
}

Received: 1 May 2014 - Published in SOIL Discuss.: 14 May 2014

Revised: - - Accepted: 5 July 2014 - Published: 6 January 2015

\begin{abstract}
The idea that human health is tied to the soil is not a new one. As far back as circa $1400 \mathrm{BC}$ the Bible depicts Moses as understanding that fertile soil was essential to the well-being of his people. In $400 \mathrm{BC}$ the Greek philosopher Hippocrates provided a list of things that should be considered in a proper medical evaluation, including the properties of the local ground. By the late 1700s and early 1800s, American farmers had recognized that soil properties had some connection to human health. In the modern world, we recognize that soils have a distinct influence on human health. We recognize that soils influence (1) food availability and quality (food security), (2) human contact with various chemicals, and (3) human contact with various pathogens. Soils and human health studies include investigations into nutrient supply through the food chain and routes of exposure to chemicals and pathogens. However, making strong, scientific connections between soils and human health can be difficult. There are multiple variables to consider in the soil environment, meaning traditional scientific studies that seek to isolate and manipulate a single variable often do not provide meaningful data. The complete study of soils and human health also involves many different specialties such as soil scientists, toxicologists, medical professionals, anthropologists, etc. These groups do not traditionally work together on research projects, and do not always effectively communicate with one another. Climate change and how it will affect the soil environment/ecosystem going into the future is another variable affecting the relationship between soils and health. Future successes in soils and human health research will require effectively addressing difficult issues such as these.
\end{abstract}

\section{Introduction}

Many people probably think about things such as an active exercise program, wise food choices, good medical care, and proper sanitation when they consider their health, but few probably think about soils. The truth is soils form an integral link in the holistic view of human health, and some have recognized there are connections between soil and human health going back thousands of years. While the group that actively recognizes soils are important to human health is probably still in the minority when considering the human population at large, many advances have been made in the study of soils and human health. This paper will review some of the more important of these advances, explore where the field of soils and human health is today, and offer some opinions regarding future needs in soils and human health research.

\section{Soils and human health prior to the 21st century}

The idea that there are links between soils and human health is an ancient one. The Bible depicts Moses as understanding that fertile soil was essential to the well-being of his people circa $1400 \mathrm{BC}$ as they entered Canaan: "See what the land is like and whether the people who live there are strong or weak, few or many. What kind of land do they live in? Is it good or bad?... How is the soil? Is it fertile or poor? Are there trees on it or not? Do your best to bring back some of the fruit of the land." (Numbers 13:18-20). Likewise, in 400 BC Hippocrates provided a list of things that should be considered in a proper medical evaluation. The list included the ground: “... whether it be naked and deficient in water, or wooded and well-watered, and whether it lies in a hollow, confined situation, or is elevated and cold..." (Hippocrates, 2010). And in 60 BC, the Roman writer Columella discussed 
hidden diseases contracted from marshes, which even physicians did not understand (Sylvia et al., 1998). Therefore, even though most in the ancient world viewed illness as punishment from the gods (Queijo, 2010), some were beginning to realize that the natural world, including soils, played a role in human health. Recognition of the fact there are relationships between soils and human health date to some of the earlier days of human soil knowledge (Brevik and Hartemink, 2010).

In the late 1700s, in Letters from an American Farmer, de Crèvecoeur wrote, "Men are like plants; the goodness and flavor of the fruit proceeds from the peculiar soil and exposition in which they grow" (de Crèvecoeur, 1904), and Stoll (2002) noted that in the early 1800s some North American farmers recognized a link between agriculture and an enduring society. Therefore, humans did recognize to at least some extent the importance of soils to overall human health before, and in some cases thousands of years before, the 20th century. However, this recognition was based on casual observations leading to logical conclusions rather than scientific investigation.

In the 1900s the idea that soils influence human health gained considerable traction. In 1921 Robert McCarrison published Studies in Deficiency Disease. McCarrison (1921) concluded that the fertility of a soil determined the vitamin content of food crops grown in it, and therefore influenced human health. He also speculated that soil bacteria could contribute to human diseases.

At least three chapters in the 1938 USDA Yearbook of Agriculture included recognition of the importance of soil as the origin of many of the mineral elements necessary for human health (Browne, 1938; Kellogg, 1938; McMurtrey and Robinson, 1938). The US Department of Agriculture (USDA) established the Plant, Soil and Nutrition Research Unit (PSNRU) on the Cornell University campus in 1940. The PSNRU's original mission was to conduct research at the interface of human nutrition and agriculture to improve the nutritional quality and health promoting properties of food crops. The PSNRU mission has expanded since its founding, but soils and human health is still a major research area (PSNRU, 2008). By the 1950s USDA scientists had realized that soils were not only important in the supply of essential nutrients; they could also supply toxic levels of elements to the human diet (Bear, 1957).

On 22 March 1939 a 31-member medical committee representing County Palatine of Chester in the United Kingdom published a document titled Medical Testament (Kerr et al., 1939). In this testament, the committee acknowledged that life expectancies in the UK had increased. However, the committee also concluded that despite this increase in life expectancy, illness was also on the rise and that this rise in illness was due to poor nutrition in the typical British diet. Furthermore, the committee concluded that the poor nutrition in British food was due to agricultural practices that exhausted the soil of essential nutrients. The medical commit- tee concluded that roughly half the work of medical personnel in Britain was wasted due to the poor nutritional quality of British food, and that significant advances in reducing human illness rates would only be achieved by addressing the underlying causes of food quality, which required restoration of soil fertility.

Government agencies were not the only groups recognizing connections between soils and human health in the first half of the 20th century. A 1940 work by R. A. Hayne, published by the International Harvester Company of Chicago, Illinois, USA, noted that poor soils led to "stoop-shouldered, poverty-stricken people" and "if we feed the soil it will feed us". Hayne (1940) went on to state that "only productive soil can support a prosperous people" and "to be properly and healthfully fed we must have food from soils containing the elements necessary to maintain good health". Hayne (1940) also noted the importance of nutrient transfer from soils to animals to humans.

A major human health breakthrough in 1940 was the isolation of antibiotic compounds from soil organisms by the research group at Rutgers University lead by Selman Waksman. Soil microorganisms create antibiotic compounds in an effort to gain a competitive advantage in the soil ecosystem. Humans have been able to isolate those compounds and use them advantageously in the fight against bacterial infections. Waksman was awarded the Nobel Prize in Physiology or Medicine in 1952 for this work (Brevik, 2009a).

Also in 1940 Sir Albert Howard published An Agricultural Testament. Although primarily a work promoting organic agriculture, Howard devoted a chapter to the effects of soil fertility on human health. Howard followed this up in 1947 with his work The Soil and Health: A Study of Organic Agriculture. Again, although best known for its substantial influence on the organic agriculture movement, this work also includes a chapter on soil fertility and human health. In both chapters Howard began by outlining the difficulties inherent in studying the links between soils and human health. He then reviews work done on the topic to that point by other researchers, and examples of links between the types of foods consumed and human health are given. In The Soil and Health, Howard also provides examples of various groups around the world renowned for good health, and the relationship these groups have with the land was discussed. Howard's conclusion in both books was that the health of the soil that foods are grown in affects the health of the people who consume the foods.

The Living Soil was published by Lady Eve Balfour in 1943. This work began with a discussion of what soil is and the threat erosion posed to soil fertility. Balfour goes on to discuss how much human illness is likely caused by inadequate nutrition as a result of the foods we consume. After discussing various lines of evidence that the condition and fertility of the soil is important to the nutrient content of food crops grown in that soil, and thus human health, Balfour con- 
cluded that we need to change our approach to agriculture and our thinking about the role of soils in human health.

J. I. Rodale's 1945 book Pay Dirt: Farming and Gardening with Composts devoted two chapters to human health as it relates to soil. Rodale stated that we have been mining our soil, and that the use of chemical fertilizers has led to a change in the nutrient value of crops raised for our food supply because typical chemical fertilizers do not return all of the nutrients removed by crops. As evidence, Rodale cited increases in heart disease in the parts of the United States that had been farmed the longest. He also speculated that increases in mental health problems could be related to nutrition deficiencies. Rodale (1945) concluded that the vitamin content of our food is dependent on the soils in which they are grown, and that many American health problems are related to the soils in which our food supply is grown.

In the 1940s and 1950s William Albrecht of the University of Missouri became interested in links between soils and human health, an interest that led to the publication of several papers. Albrecht's works focused on links between soil fertility and dental health, with a particular focus on the relationships between soil fertility and dental cavities (caries) (e.g., Albrecht, 1945; 1951). However, Albrecht did extend the relationships between soil fertility and human health out to broader, more general health issues in some of his writings. For example, Albrecht (1957) concluded that excessively weathered tropical soils led to "malignant nutrition", or a general breakdown of body functions, because these soils lacked the proper nutrients to allow for the appropriate synthesis of proteins in the local food supply. Conversely, Albrecht (1957) concluded that the overall environmental conditions of locations such as the midwestern United States allowed for fertile soils and proper protein production for good health. While Albrecht's conclusions were not all correct, he did recognize that links existed between the fertility of a soil and the nutritional value of the plants grown in that soil, and that this carried up the food chain to the animals, including humans, who depended on products grown in that soil.

André Voisin published Soil, Grass, and Cancer in 1959. This was an extensive work devoted to ties between soils and human health. Voisin began his book by noting that human cells are composed of mineral elements that originate in the soil, and that humans are a "biochemical photograph" of the soils in the environment in which we grow our food. Voisin also noted that getting a clear picture of how a given soil influences human health was a difficult undertaking due to the international trade of food products, meaning any given person received nutrients from a wide geographic range of soils. Much of Voisin's (1959) work focused on nutrient content in soils, including both nutrient deficiencies and imbalances, and how they influence nutrient status in plants and animals that are in turn consumed by humans. Several health problems were discussed, including but not limited to birth defects, goiter, mental illness, diabetes, and cancer. Voisin (1959) also points out ancient folk knowledge that in- dicates an understanding of soil-human health relationships by our ancestors in numerous places throughout the book. He concluded that the medical profession had largely ignored soils in their efforts to improve human health, but that soil science should be the foundation of preventative medicine.

Soils and human health studies continued in the later part of the 20th century, with publications related to soils and human health being too numerous to list completely. Therefore, examples will be given. The health effects of exposures to radioactive elements in soils received considerable attention after the 1986 Chernobyl incident (e.g., Elstner et al., 1987; Wynne, 1989; Balonov et al., 1999; Dushenkov et al., 1999). However, even prior to Chernobyl, radionuclides in the soil and how they may affect human health were receiving attention (e.g., Comar, 1960; Franca et al., 1965; Cohen and Jow, 1978; Adriano, 1979). Investigations into the effects of heavy metals in soils became a common theme (e.g., Walsh et al., 1977; Morgan and Simms, 1988; Strehlow and Barltrop, 1988; Fergusson, 1990; Alloway, 1995; Albering et al., 1999), as did organic chemicals in soils (e.g., Pettry et al., 1973; Calvet, 1989; Sedman, 1989; Chaudhry and Chapalamadugu, 1991; Pohl et al., 1995; Simcox et al., 1995). Geophagy, the practice of eating soil, has attracted the interest of anthropologists and geographers for many years (e.g., Laufer, 1930; Dickins and Ford, 1942; Hertz, 1947; Cooper, 1957; Anell and Lagercrantz, 1958; Halsted, 1968) and remained a subject of study (e.g., Vermeer and Frate, 1979; Danford, 1982; Frate, 1984; Abrahams and Parsons, 1996; Calabrese et al., 1997). The effects of trace elements on human health received attention (e.g., Underwood, 1956; Sorenson et al., 1974; Thomson and Robinson, 1980; Cakmak et al., 1996; Mills, 1996; Senesil et al., 1999). In the mid-1980s selenium was added to all micronutrient fertilizers in Finland to compensate for low selenium levels in crops; this was successful in increasing the selenium uptake of the Finnish population (Varo et al., 1988). Following up on the discovery of antibiotics, soil organisms received increased attention as they related to human health (e.g., Rangaswami and Ethiraj, 1962; Lechevalier and Lechevalier, 1967; Bérdy, 1974). About $78 \%$ of antibacterial agents and $60 \%$ of new cancer drugs approved between 1983 and 1994 had their origins in the soil, as did about $60 \%$ of all newly approved drugs between 1989 and 1995 (Pepper et al., 2009). In addition to the medicines derived from soils and soil organisms, it was also recognized that soil organisms could cause illness (e.g., Bagdasaryan, 1964; Duboise et al., 1976; Brown et al., 1979; Rowbotham, 1980; Hagedorn et al., 1981; Waldron, 1985; Gilles and Ball, 1991) (Fig. 1).

By the end of the 20th century, M. A. Oliver (1997) noted that "... there is a dearth of quantitative information on the relations between elements in the soil and human health;... there is much speculation and anecdotal evidence." The idea that soils influence human health is not new; it has existed for thousands of years and gained considerable atten- 

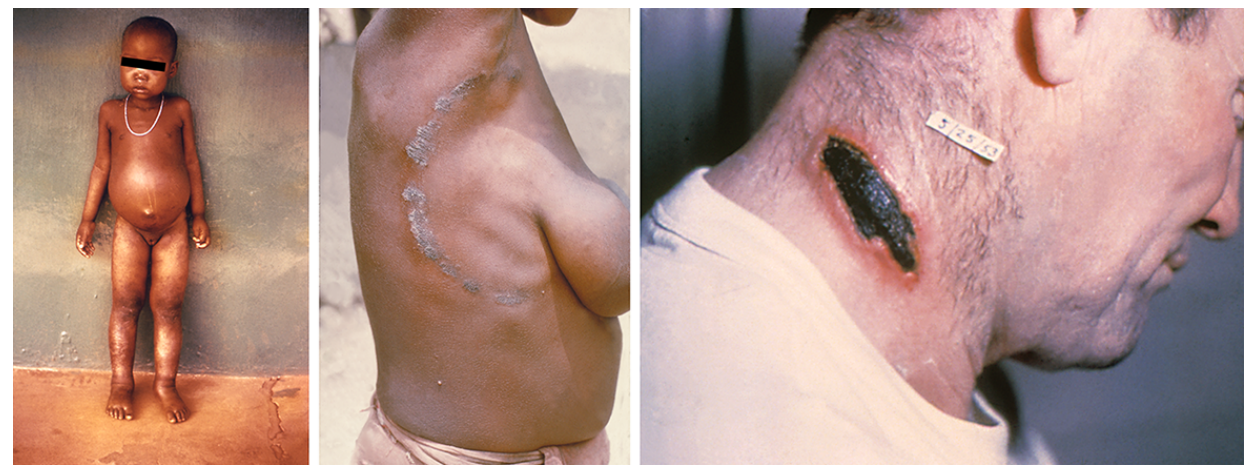

Figure 1. A child with hookworm showing visible signs of edema, was also diagnosed with anemia (left); ringworm on the skin of the right axilla and flank due to Trichophyton rubrum (middle); anthrax lesion on the neck (right). These health problems are caused by helminthes, fungi, and bacteria found in the soil, respectively. (Courtesy of the Centers for Disease Control and Prevention, images \#5243, \#482, and \#1934.)

tion in the 20th century. However, the scientific study of soils and human health is a recent undertaking.

\section{The present}

A number of articles have been published over the last 10 years reviewing the status of our knowledge of soils and human health (e.g., Deckers and Steinnes, 2004; Hough, 2007; Brevik, 2009a, 2013a; Pepper et al., 2009; Handschumacher and Schwartz, 2010; Steinnes, 2011; Pepper, 2013). Books addressing soils and human health are also being published. Skinner and Berger (2003) and Selinus et al. (2005) produced volumes that focus on links between geology and human health, but several of the chapters in both works address soil topics as well. Brevik and Burgess (2013a) edited a volume that is the first modern book to focus exclusively on the links between soils and human health. Modern research has led us to recognize that soils influence human health through (1) food availability and quality (food security), (2) human contact with various chemicals, and (3) human contact with various pathogens (Brevik, 2013a; Burras et al., 2013).

The PSNRU remains active in soils and human health research, but it is not the only US government agency involved in soils and human health research. Agencies such as the US Geological Survey, the Centers for Disease Control and Prevention (Selinus et al., 2005), and the Department of Energy (Turick et al., 2013) are also involved, as are other branches of the USDA (Selinus et al., 2005; Gardner et al., 2012). The USDA Natural Resources Conservation Service (NRCS) has recently made soil health a major focus of the agency (NRCS, 2014), and soil health is important to human health (Doran and Zeiss, 2000). Other governments have soils and human health work being conducted by their agencies as well. For example, the British Geological Survey, Geological Survey of Canada, and Geology Survey of Sweden have all devoted recent efforts to soils and human health topics (Selinus et al., 2005).

Many topics are investigated in the modern soils and human health community. One of the major topics involves the transfer of nutrients from soil to people. This may involve the transfer from soils to plants to people (e.g., Rayman, 2000; Cakmak, 2002, 2008; Kabata-Pendias and Mukherjee, 2007; Spiegel et al., 2009), from soils to plants to animals to people (e.g., Jones, 2005; Klasing et al., 2005), or even directly from soils to people (e.g., Smith et al., 2000; Abrahams et al., 2006; Hooda and Henry, 2007; Young, 2007). In all cases, the fundamental idea is that many essential human nutrients begin in the soil and are passed on to humans through the food chain. This has interesting ramifications as we consider nutrient cycling in a world that is becoming highly altered by human activities, including processes that occur in soil (Richter et al., 2011; Brevik, 2012). For example, human interference in the $\mathrm{N}$ cycle through inputs such as fertilizers, production of $\mathrm{N}$-fixing crops, and the addition of wastes to soil have been shown to have negative health effects (Driscoll et al., 2003).

Research into toxic exposures to various chemicals continues to receive significant attention. This topic includes heavy metals (e.g., Kibble and Saunders, 2001; Filippelli and Laidlaw, 2010; Taylor et al., 2010; Weindorf et al., 2013; Burt et al., 2014), radioactive materials (e.g., Yamada, 2003; Appleton, 2007; Hu et al., 2010), and organic chemicals (e.g., Albihn, 2001; Horrigan et al., 2002; Lee et al., 2003; Chamignon et al., 2008). Soil pathogens have also continued to receive attention (e.g., Jovic et al., 2001; Jenkins et al., 2002; Ross and Donnison, 2006; Fisher et al., 2007; Brevik and Burgess, 2013b). Additional benefits of soil organisms have been revealed; it is now thought that exposure to soil microorganisms is important in the prevention of allergies and other immunity-related disorders (Kay, 2000; Matricardi and Bonini, 2000; Haahtela et al., 2008; Rook, 2010). Phytoremediation of both heavy metals and organic chemicals has received attention (Tu et al., 2002; Cho et al., 2013; Ye et 
al., 2014), as well as human exposures to contaminates obtained by plants through soils and passed up the food chain (Khan et al., 2008; Zhuang et al., 2009; Roy and McDonald, 2013). Work in geophagy frequently gets tied into these studies, because the deliberate ingestion of soil can lead to exposure to hazardous materials and soil organisms (e.g., Wilson, 2003; Abrahams, 2005; Shigova and Moturi, 2009; Young et al., 2010; Henry and Cring, 2013). The health effects of dust generated from soil sources has also seen recent interest. This has included direct effects of dust on the respiratory system (Sharratt and Lauer, 2006; Whicker et al., 2006; Buck et al., 2013) as well as indirect effects through exposure to pathogens (Bultman et al., 2005; Gardner et al., 2012) or pollutants (Chen et al., 2005; Boxall et al., 2009) carried on dust.

Some research involves less direct influences of soils on human health. Soil and water interactions and how they play into human health is an area that receives study in the current research environment. Interactions between soil and water can lead to exposures including toxic levels of hazardous materials (Kolpin et al., 2000; Harvey et al., 2006; Dubrovsky and Hamilton, 2010) and pathogens (Jamieson et al., 2002; Nasser et al., 2003; McLeod et al., 2008; Loynachan, 2013) in the local water supply. A famous example of hazardous materials introduced to groundwater from soil is arsenic in Bangladesh, a problem encountered when Bangladesh switched from surface sources of drinking water to groundwater to avoid human exposure to enteric pathogens (Helmke and Losco, 2013). Soils can also positively influence human health by acting as a filter to remove hazardous materials and pathogens (Lal and Shukla, 2004; Zhang and Selim, 2005; Torkzabana et al., 2006). Soils are critical to food security (Pimentel, 2006; Lal, 2010; Blum and Nortcliff, 2013; Brevik, 2013a), and nutritious food is essential for human health (Cakmak, 2002; Brevik, 2009a). Modern research focused on the links between erosion and food security clearly demonstrates that soil erosion threatens to undermine global food security (Lal, 2010; Pimentel and Burgess, 2013) and thus human health (Fig. 2).

\section{Future topics and challenges}

Research into all of the areas discussed as current soils and human health topics has led to significant advances, but more information is still needed in all these areas. In addition, there is a pressing need for synergistic studies in several other areas. One of these is investigations into the interactive relationships between chemicals found in the environment. A good example of this interactive relationship has been observed with $\mathrm{Cd}$. High levels of $\mathrm{Cd}$ in soil was identified as causing itai-itai disease in Toyama Prefecture, Japan, however, soil solution levels similarly high in $\mathrm{Cd}$ do not seem to cause health problems for people living in Shipham, England (Morgan, 2013). Several hypotheses have been offered

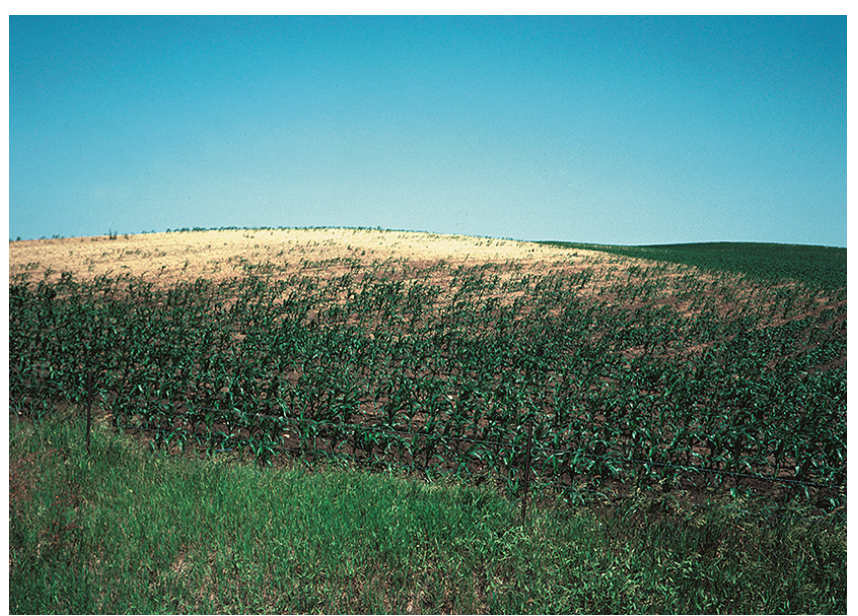

Figure 2. The loss of nutrient-rich topsoil along the top of this hill has compromised the ability of the soil to support crops as shown by the visibly reduced vegetative growth. Productivity losses such as this can jeopardize food security, and thus human health, if they occur over large areas. (Photo by Gene Alexander, USDA NRCS.)

to explain this discrepancy. One revolves around the fact that when $\mathrm{Fe}$ and $\mathrm{Zn}$ are deficient in the diet, Cd retention is increased 15 times relative to people who have adequate $\mathrm{Fe}$ and $\mathrm{Zn}$ in their diets. The Japanese diet was Fe and $\mathrm{Zn}$ deficient compared to the English diet, possibly explaining the differences in observed health affects (Davies et al., 2005). Another possible explanation revolves around the slightly alkaline $\mathrm{pH}$ of the English soils, which reduces the bioavailability of the $\mathrm{Cd}$ and also likely provides elements such as $\mathrm{Ca}$ that interfere with $\mathrm{Cd}$ uptake by humans. In addition, because of a varied diet, overall $\mathrm{Cd}$ levels in the average Shipham resident's diet were much lower than in the average diet of regions in Japan were itai-itai was a problem (Morgan, 2013). In a similar manner, little is known about the ways that organic chemicals are transformed when they are introduced to the soil or the ways that multiple organic compounds combined in the soil interact with humans exposed to them (Burgess, 2013). Studies that account for these interactive relationships are needed.

Research is needed to investigate the ecology and life cycles of organisms that spend all or part of their life in the soil. Soil pathogens are a significant source of human health problems (Bultman et al., 2005; Loynachan, 2013) and knowledge of an organism's natural ecology aids in understanding its pathogenic potential (Revnakar and Sutton, 2010). However, some disease outbreaks such as the 2012 fungal meningitis outbreak in the United States (Brevik and Burgess, 2013b) (Fig. 3) or the valley fever outbreaks that occasionally occur in the southwestern United States (Tabor et al., 2011) are caused by organisms who's soil ecology is not well understood. An increased emphasis on the study of soil organisms would also be important in developing new medications (Pepper et al., 2009; Mbila, 2013) and ensuring food security 


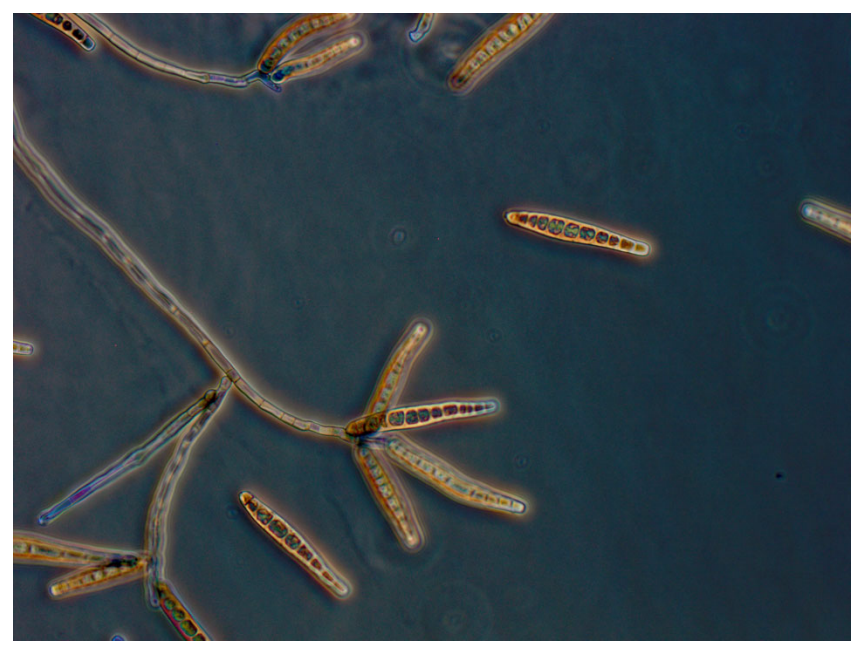

Figure 3. A magnified photograph of the dematiaceous fungus Exserohilium rostratum, the fungus implicated in the 2012 fungal meningitis outbreak in the United States. (Courtesy of the Centers for Disease Control and Prevention.)

through agricultural production (Brevik, 2009b). Therefore, better knowledge of soil ecology and organisms has the potential to improve human health in several ways.

There are many ways that climate change is expected to influence human health, including contributing to temperature extremes (Kalkstein and Greene, 1997; Ebi et al., 2008), deteriorating air quality (Beggs and Bambrick, 2005; Pyle et al., 2007; Boxall et al., 2009; English et al., 2009), and reduced food security (Parry et al., 2005; Kang et al., 2009; Lal, 2010; Sauer and Nelson, 2011; Brevik, 2013c). Soils interact with the atmosphere and therefore take part in the changes that are occurring in atmospheric chemistry (Brevik, 2012) that are driving climate change (IPCC, 2007). This means soils have both indirect and direct impacts on human health as it is affected by climate change (Brevik, 2013b). Our understanding of how soils influence climate change as well as how climate change influences soils is still incomplete (Brevik, 2012). Therefore, there is an urgent need to study the effects of climate change on soils and how interactions between soils and climate may influence human health.

The disposal of e-wastes (hazardous wastes generated by the proliferation of electronic devices in modern society) and their potential effects on the environment have become a major concern as humans increasingly use electronic devices to manage their lives (Ha et al., 2009; Robinson, 2009; Guo et al., 2010; Frazzoli et al., 2011; Morgan, 2013). E-wastes include compounds from televisions, monitors, computers, audio and stereo equipment, video cameras, telephones, fax and photocopy machines and printers, mobile phones, wireless devices, integrated circuits (chips), motherboards, cathode ray tubes (CRTs), and other items. (Frazzoli et al., 2011). Ewastes may introduce heavy metals (Ha et al., 2009; Robinson, 2009) and organic chemicals (Robinson, 2009) into soil.
In many developing countries the processing of e-wastes is not well regulated, which has led to significant contamination in some e-waste recycling centers (Leung et al., 2008). However, the potential pathways of human exposure to these materials are difficult to evaluate (Morgan, 2013). Exactly what role soils may play in these exposures is an important area for future study.

A less traditional area that needs study is the possible health benefits from direct soil contact. This line of research follows in the tradition of studies that show improved human health through plant/nature contact (e.g., Ulrich, 1984; Cimprich, 1993; Lohr and Pearson-Mins, 2002; Relf and Lohr, 2003; Biederman and Vessel, 2006; Barton and Pretty, 2010). Although not always acknowledged, the foundation of these plant/nature interactions is soil, and it is therefore logical to conclude that contact with healthy soil could itself provide some measure of benefit to human health (Heckman, 2013). There have also been indications that interaction with soil can have a relaxing effect on humans (Hanyu et al., 2014). Likewise, there are many with strong beliefs that organic farming is better for human health than conventional farming, but additional research is needed to investigate this (Carr et al., 2013). Only the implementation of well-designed studies will provide definitive answers to these less traditional questions.

Another future issue we need to confront is how well traditional funding agencies/pathways and ways of establishing priorities for the distribution of research funds work in addressing the soils and human health topic. A recent review of soil physics papers showed that none of them were funded by groups that fund human health research (Kirkham, 2012), even though soil physicists frequently investigate topics that have relevance to human health. If soils are an important component of human health, should groups that fund studies into human health topics also not fund relevant soils research? And if these groups will not fund that research, who will?

Finally, there is a need to educate broad groups of people about the links between soils and human health. Courses that cover soils and human health relationships are not common in our education systems, and soil scientists often do not work with health professionals such as medical doctors or human health researchers (Brevik and Burgess, 2013b). General education courses in our universities would be useful to expose large groups of educated individuals to this topic, and upper level courses are needed to train future researchers. This includes the need for books that can be used as textbooks in these courses (e.g., Brevik and Burgess, 2013a; Selinus et al., 2005) and other education-focused materials in this area (e.g., Brevik and Burgess, 2014). 


\section{Conclusions}

There is a long history documenting the recognition that soils are important to human health. However, up until the late 20th century much of this recognition was based on antecedent evidence rather than sound scientific research. Rigorous, well-designed scientific studies in this area are needed. These studies must involve interdisciplinary collaboration as narrow research efforts will not be able to adequately address many of the issues we need to investigate (Handschumacher and Schwartz, 2010; Brevik and Burgess, 2013b). Complex interdisciplinary research teams are needed with expertise in relevant areas and the ability for team members to communicate effectively with one another at a professional level. Many disciplines are involved in soils and human health research (e.g., soil science, geology, geography, anthropology, biology, agronomy, sociology, public health, the medical professions, etc.), and not all of these disciplines traditionally work together. Looking to the future, research is needed in many areas related to the soils and human health issue. These include

- all areas of traditional soils and human health research;

- chemical interactions in the soil, because few chemical species behave or interact with humans and other organisms individually in the soil environment;

- soil ecology of pathogenic organisms, which will aid in understanding their pathogenic potential;

- soil-climate change-human health interactions, as soils and the atmosphere are intricately linked and atmospheric changes affect human health;

- contaminant pathways involving e-wastes, as the volume of e-wastes is on the rise but the place of soil in exposure pathways to these materials is difficult to evaluate;

- possible health benefits to be derived from working with soil, in line with past research into the benefits of plant/nature contact;

- how well current funding protocols address soils and human health research needs;

- the need to educate the public and train future researchers in this area.

Evidence indicates that understanding the links between soils and human health should be given more importance in human health research than it currently receives.

Acknowledgements. This paper is based on a presentation given in the Milestones in Soil Science Research session at the 2012 European Geosciences Union meeting.

Edited by: J. Homburg

\section{References}

Abrahams, P. W.: Geophagy and the involuntary ingestion of soil, in: Essentials of Medical Geology, edited by: Selinus, O., A1loway, B., Centeno, J. A., Finkelman, R. B., Fuge, R., Lindh, U., and Smedley, P., Amsterdam, The Netherlands, Elsevier, 435458, 2005.

Abrahams, P. W. and Parsons, J. A.: Geophagy in the tropics: a literature review, Geogr. J., 162, 63-72, 1996.

Abrahams, P. W., Follansbee, M. H., Hunt, A., Smith, B., and Wragg, J.: Iron nutrition and possible lead toxicity: An appraisal of geophagy undertaken by pregnant women of U.K. Asian communities, Appl. Geochem., 21, 98-108, 2006.

Adriano, D. C.: Factors affecting the availability of Americium-241 to the rice plant, J. Agric. Food Chem., 27, 1369-1375, 1979.

Albering, H. J., van Leusen, S. M., Moonen, E. J. C., Hoogewerff, J. A., and Kleinjans J. C. S.: Human health risk assessment: a case study involving heavy metal soil contamination after the flooding of the River Meuse during the winter of 1993-1994, Environ. Health Persp., 107, 37-43, 1999.

Albihn, A.: Recycling biowaste-Human and animal health problems, Acta Vet. Scand., Suppl., 95, 69-75, 2001.

Albrecht, W. A.: Soil fertility and its health implications, Journal of Orthodontics and Oral Surgery, 31, 279-286, 1945.

Albrecht, W. A.: Pattern of caries in relation to the pattern of soil fertility in the United States, The Dental Journal of Australia, 23, 1-6, 1951.

Albrecht, W. A.: Soil fertility and biotic geography, Geogr. Rev., 47, 86-105, 1957.

Alloway, B. J.: Soil processes and the behaviour of heavy metals, in: Heavy Metals in Soils, edited by: Alloway, B. J., London, UK, Blackie Academic \& Professional, 2nd Edn., 11-37, 1995.

Anell, B. and Lagercrantz, S.: Geophagical customs, Studia Ethnographica Upsaliensia 17, Stockholm, Sweden, Humanistiska Fonden, 1958.

Appleton, J. D.: Radon: Sources, health risks, and hazard mapping, Ambio, 36, 85-89, 2007.

Bagdasaryan, G. A.: Survival of viruses of the enterovirus group (poliomyelitis, echo, coxsackie) in soil and on vegetables, J. Hyg. Epid. Microb. Im., 8, 497-505, 1964.

Balfour, E. B.: The living soil, London, UK, Faber and Faber Ltd., 1943.

Balonov, M. I., Krisyuk, E. M., and Ramel, C.: Environmental radioactivity, population exposure and related health risks in the east Baltic region, Scand. J. Work Env. Hea., 25, 17-32, 1999.

Barton, J. and Pretty, J.: What is the best dose of nature and green exercise for improving mental health? A multi-study analysis, Environ. Sci. Technol., 44, 3947-3955, 2010.

Bear, F. E.: Toxic elements in soils, in: Soil: The 1957 yearbook of agriculture, edited by: Stefferud, A., Washington, DC, USA, United States Government Printing Office, 165-171, 1957.

Beggs, P. J. and Bambrick, H. J.: Is the global rise of asthma an early impact of anthropogenic climate change?, Environ. Health Persp., 113, 915-919, 2005.

Bérdy, J.: Recent developments of antibiotic research and classification of antibiotics according to chemical structure, Adv. Appl. Microbiol., 18, 309-406, 1974.

Biederman, I. and Vessel, E. A.: Perceptual pleasure and the brain, Am. Sci., 94, 247-253, 2006. 
Blum, W. E. H. and Nortcliff, S.: Soils and food security, in Soils and human health, edited by: Brevik, E. C. and Burgess, L. C., Boca Raton, FL, USA, CRC Press, 290-321, 2013.

Boxall, A. B. A., Hardy, A., Beulke, S., Boucard, T., Burgin, L., Falloon, P. D., Haygarth, P. M., Hutchinson, T., Kovats, R. S., Leonardi, G., Levy, L. S., Nichols, G., Parsons, S. A., Potts, L., Stone, D., Topp, E., Turley, D. B., Walsh, K., Wellington, E. M. H., and Williams, R. J.: Impacts of climate change on indirect human exposure to pathogens and chemicals from agriculture, Environ. Health Persp., 117, 508-514, 2009.

Brevik, E. C.: Soil, food security, and human health, in: Soils, Plant Growth and Crop Production, edited by: Verheye, W., Encyclopedia of Life Support Systems (EOLSS), Developed under the Auspices of the UNESCO, Oxford, UK, EOLSS Publishers, available at: http://www.eolss.net (last access: 17 December 2013), 2009a.

Brevik, E. C.: Soil health and productivity, in: Soils, Plant Growth and Crop Production, edited by: Verheye, W., Encyclopedia of Life Support Systems (EOLSS), Developed under the Auspices of the UNESCO, Oxford, UK, EOLSS Publishers, available at: http://www.eolss.net (last access: 17 December 2013), 2009b.

Brevik, E. C.: Soils and climate change: Gas fluxes and soil processes, Soil Horiz., 53, 12-23, doi:10.2136/sh12-04-0012, 2012.

Brevik, E. C.: Soils and human health - an overview, in: Soils and human health, edited by: Brevik, E. C. and Burgess, L. C., Boca Raton, FL, USA, CRC Press, 29-56, 2013a.

Brevik, E. C.: Climate change, soils, and human health, in: Soils and human health, edited by: Brevik, E. C. and Burgess, L. C., Boca Raton, FL, USA, CRC Press, 345-383, 2013 b.

Brevik, E. C.: The potential impact of climate change on soil properties and processes and corresponding influence on food security, Agriculture, 3, 398-417, 2013c.

Brevik, E. C. and Burgess, L. C. (Eds.): Soils and human health, Boca Raton, FL, USA, CRC Press, 2013a.

Brevik, E. C. and Burgess, L. C.: The 2012 fungal meningitis outbreak in the United States: Connections between soils and human health, Soil Horiz., 54, 1-4, doi:10.2136/sh12-11-0030, 2013b.

Brevik, E. C. and Burgess, L. C.: The influence of soils on human health. Nature Education, in press, 2014.

Brevik, E. C. and Hartemink, A. E.: Early soil knowledge and the birth and development of soil science, Catena, 83, 23-33, 2010.

Brown, K. W., Wolf, H. W., Donnelly, K. C., and Slowey, J. F.: The movement of fecal coliforms and coliphages below septic lines, J. Environ. Qual., 9, 121-125, 1979.

Browne, C. A.: Some relationships of soil to plant and animal nutrition - the major elements, in: Soils and Men: Yearbook of Agriculture 1938, edited by: Knight, H. G., Kellogg, C. E., Barnes, C. P., McCall, M. A., Allin, B. W., Patrick, A. L., Baker, O. E., Enlow, C. R., Bressman, E. N., Munns, E. N., and Hambidge, G., Washington, DC, USA, United States Government Printing Office, 777-806, 1938.

Buck, B. J., Goossens, D., Metcalf, R. V., McLaurin, B., Ren, M., and Freudenberger, F.: Naturally occurring asbestos: Potential for human exposure, Southern Nevada, USA, Soil Sci. Soc. Am. J., 77, 2192-2204, 2013.

Bultman, M. W., Fisher, F. S., and Pappagianis, D.: The ecology of soil-borne human pathogens, in: Essentials of Medical Geology, edited by: Selinus, O., Alloway, B., Centeno, J. A., Finkelman, R. B., Fuge, R., Lindh, U., and Smedley, P., Amsterdam, The Netherlands, Elsevier, 481-511, 2005.
Burgess, L. C.: Organic pollutants in soil, in Soils and human health, edited by: Brevik, E. C. and Burgess, L. C., Boca Raton, FL, USA, CRC Press, 83-106, 2013.

Burras, C. L., Nyasimi, M., and Butler, L.: Soils, human health, and wealth: A complicated relationship, in: Soils and human health, edited by: Brevik, E. C. and Burgess, L. C., Boca Raton, FL, USA, CRC Press, 215-226, 2013.

Burt, R., Chiaretti, J. V., and Ferguson, R.: Chemical fractionation of selected Nevada soils adjacent to the Sierra Army Depot, Soil Horiz., 55, doi:10.2136/sh13-07-0019, 2014.

Cakmak, I.: Plant nutrition research: Priorities to meet human needs for food in sustainable ways, Plant Soil, 247, 3-24, 2002.

Cakmak, I.: Enrichment of cereal grains with zinc: Agronomic or genetic biofortification?, Plant Soil, 302, 1-17, 2008.

Cakmak, I., Yilmaz, A., Kalayci, M., Ekiz, H., Torun, B., Erenoglu, B., and Braun, H. J.: Zinc deficiency as a critical problem in wheat production in Central Anatolia, Plant Soil, 180, 165-172, 1996.

Calabrese, E. J., Stanek, E. J., James, R. C., and Roberts, S. M.: Soil ingestion: a concern for acute toxicity in children, Environ. Health Persp., 105, 1354-1358, 1997.

Calvet, R.: Adsorption of organic chemicals in soils, Environ. Health Persp., 88, 145-177, 1989.

Carr, P. M., Delate, K., Zhao, X., Cambardella, C. A., Carr, P. L., and Heckman, J. R.: Organic farming impacts on soil, food, and human health, in: Soils and human health, edited by: Brevik, E. C. and Burgess, L. C., Boca Raton, FL, USA, CRC Press, 241258, 2013.

Chamignon, C., Haroune, N., Forano, C., Delort, A.-M., BesseHoggan, P., and Combourieu, B.: Mobility of organic pollutants in soil components, What role can magic angle spinning NMR play?, Eur. J. Soil Sci., 59, 572-583, 2008.

Chaudhry, G. R. and Chapalamadugu, S.: Biodegradation of halogenated organic compounds, Microbiol. Rev., 55, 59-79, 1991.

Chen, T. B., Zheng, Y. M., Lei, M., Huang, Z. C., Wu, H. T., Chen, H., Fan, K. K., Yu, K., Wu, X., and Tian, Q. Z.: Assessment of heavy metal pollution in surface soils of urban parks in Beijing, China, Chemosphere, 60, 542-551, 2005.

Cho, C., Park, S., and Sung, K.: Subsurface and plant contamination during natural attenuation and phytoremediation of silt loam contaminated with chlorinated organic compounds, Vadose Zone J., 12, doi:10.2136/vzj2012.0081, 2013.

Cimprich, B.: Development of an intervention to restore attention in cancer patients, Cancer Nurs., 16, 83-92, 1993.

Cohen, B. L. and Jow, H. N.: Generic hazard evaluation of low-level waste burial grounds, Nucl. Technol., 41, 381-388, 1978.

Comar, C. L.: Status of surveys for radionuclides in foods, Nutr. Rev., 18, 321-324, 1960.

Cooper, M.: Pica, Springfield, IL, USA, Charles C. Thomas Publisher, 1957.

Danford, D.: Pica and nutrition, Annu. Rev. Nutr., 2, 303-322, 1982.

Davies, B. E., Bowman, C., Davies, T. C., and Selinus, O.: Medical geology: Perspectives and prospects, in: Essentials of Medical Geology, edited by: Selinus, O., Alloway, B., Centeno, J. A., Finkelman, R. B., Fuge, R., Lindh, U., and Smedley, P., Amsterdam, The Netherlands, Elsevier, 1-14, 2005.

Deckers, J. and Steinnes, E.: State of the art on soil-related geomedical issues in the world, in: Advances in agronomy, edited by: 
Sparks, D. L., Amsterdam, The Netherlands, Elsevier, Volume 84, 1-35, 2004.

de Crevecoeur, J.: Letters from an American farmer (reprinted from the original edition), New York, NY, USA, Fox and Duffield, 1904.

Dickins, D. and Ford, R.: Geophagy (dirt eating) among Mississippi negro school children, Am. Sociol. Rev., 7, 59-65, 1942.

Doran, J. W. and Zeiss, M. R.: Soil health and sustainability: managing the biotic component of soil quality, Appl. Soil Ecol., 15, 3-11, 2000.

Driscoll, C., Whitall, D., Aber, J., Boyer, E., Castro, M., Cronan, C., Goodale, C., Groffman, P., Hopkinson, C., Lambert, K., Lawrence, G., and Ollinger, S.: Nitrogen pollution: Sources and consequences in the US northeast, Environment, 45, 8-22, 2003.

Duboise, S. M., Moore, B. E., and Sagik, B. P.: Poliovirus survival and movement in a sandy forest soil, Appl. Environ. Microb., 31, 536-543, 1976.

Dubrovsky, N. M. and Hamilton, P. A.: Nutrients in the Nation's streams and groundwater: National findings and implications, US Geological Survey Fact Sheet 2010-3078, 2010.

Dushenkov, S., Mikheev, A., Prokhnevsky, A., Ruchko, M., and Sorochinsky, B.: Phytoremediation of radiocesium-contaminated soil in the vicinity of Chernobyl, Ukraine, Environ. Sci. Technol., 33, 469-475, 1999.

Ebi, K. L., Helmer, M., and Vainio, J. The health impacts of climate change: getting started on a new theme, Prehospital and Disaster Medicine, 23, S60-S64, 2008.

Elstner, E. F., Fink, R., Höll, W., Lengfelder, E., and Ziegler, H.: Natural and Chernobyl-caused radioactivity in mushrooms, mosses and soil-samples of defined biotops in SW Bavaria, Oecologia, 73, 553-558, 1987.

English, P. B., Sinclair, A. H., Ross, Z., Anderson, H., Boothe, V., Davis, C., Ebi, K., Kagey, B., Malecki, K., Shultz, R., and Simms, E.: Environmental health indicators of climate change for the United States: findings from the state environmental health indicator collaborative, Environ. Health Persp., 117, 1673-1681, 2009.

Fergusson, J. E.: The Heavy Elements: Chemistry, Environmental Impact and Health Effects, Oxford, UK, Pergamon Press, 1990.

Filippelli, G. M. and Laidlaw, M. A. S.: The elephant in the playground: Confronting lead-contaminated soils as an important source of lead burdens to urban populations, Perspect. Biol. Med., 53, 31-45, 2010.

Fisher, F. S., Bultman, M. W., Johnson, S. M., Pappagianis, D., and Zaborsky, E.: Coccidioides niches and habitat parameters in the southwestern United States: A matter of scale, Ann. NY Acad. Sci., 1111, 47-72, 2007.

Franca, E. P., Almeida, L. C., Becker, J., Emmerich, M., Roser, F. X., Kegel, G., Hainsberger, L., Cullen, T. L., Petrow, H., Drew, R., and Eisenbud, M.: Status of investigations in the Brazilian areas of high natural radioactivity, Health Phys., 11, 699-712, 1965.

Frate, D. A.: Last of the earth eaters, Sciences, 24, 34-38, 1984.

Frazzoli, C., Mantovani, A., and Orisakwe, O. E.: Electronic waste and human health, in: Encyclopedia of Environmental Health, edited by: Nriagu, J. O., Amsterdam, The Netherlands, Elsevier, 269-281, 2011.

Gardner, T., Acosta-Martinez, V., Calderón, F. J., Zobeck, T. M., Baddock, M., Van Pelt, R. S., Senwo, Z., Dowd, S., and Cox, S.:
Pyrosequencing reveals bacteria carried in different wind-eroded sediments, J. Environ. Qual., 41, 744-753, 2012.

Gilles, H. M. and Ball, P. A. J. (Eds.): Hookworm infections, Amsterdam, The Netherlands, Elsevier, 1991.

Guo, Y., Huo, X., Li, Y., Wu, K., Liu, J., Huang, J., Zheng, G., Xiao, Q., Yang, H., Wang, Y., Chen, A., and Xu, X.: Monitoring of lead, cadmium, chromium and nickel in placenta from an ewaste recycling town in China, Sci. Total Environ., 408, 31133117, 2010.

Ha, N. N., Agusa, T., Ramu, K., Tu, N. P. C., Murata, S., Bulbule, K. A., Parthasaraty, P., Takahashi, S., Subramanian, A., and Tanabe, S.: Contamination by trace elements at e-waste recycling sites in Bangalore, India, Chemosphere, 76, 9-15, 2009.

Haahtela, T., von Hertzen, L., Mäkelä, M., Hannuksela, M., Erhola, M., Kaila, M., Kauppinen, R., Killström, L., Klaukka, T., Korhonen, K., Lauerma, A., Lindgren, J., Lähteinen, S., Paakkinen, P., Pekkanen, J., Pietinalho, A., Pouta, A., Toskala, E., Vaarala, O., Valovirta, E., Vartiainen, E., and Vidgren, P.: Finnish allergy programme 2008-2018 - time to act and change the course, Allergy, 63, 634-645, 2008.

Hagedorn, C., McCoy, E. L., and Rahe, T. M.: The potential for ground water contamination from septic effluents, J. Environ. Qual., 10, 1-8, 1981.

Halsted, J. A.: Geophagia in man: its nature and nutritional effects, Am. J. Clin. Nutr., 21, 1384-1393, 1968.

Handschumacher, P. and Schwartz, D.: Do pedo-epidemiological systems exist?, in: Soil and culture, edited by: Landa, E. R. and Feller, C., New York, NY, USA, Springer, 355-368, 2010.

Hanyu, K., Tamura, K., and Mori, H.: Changes in heart rate variability and effects on POMS by whether or not soil observation was performed, Open J. Soil Sci., 4, 36-41, 2014.

Harvey, C. F., Ashfaque, K. N., Yu, W., Badruzzaman, A. B. M., Ali, M. A., Oates, P. M., Michael, H. A., Neumann, R. B., Beckie, R., Islam, S., and Ahmed, M. F.: Groundwater dynamics and arsenic contamination in Bangladesh, Chem. Geol., 228, 112-136, 2006.

Hayne, R. A.: Make the soil productive: We can't grow good crops on poor land, Educational Series 2, Chicago, IL, USA, International Harvester Company, 1940.

Heckman, J. R.: Human contact with plants and soils for health and well-being, in: Soils and human health, edited by: Brevik, E. C. and Burgess, L. C., Boca Raton, FL, USA, CRC Press, 227-240, 2013.

Helmke, M. F. and Losco, R. L.: Soil's influence on water quality and human health, in: Soils and human health, edited by: Brevik, E. C. and Burgess, L. C., Boca Raton, FL, USA, CRC Press, 155-176, 2013.

Henry, J. M. and Cring, F. D.: Geophagy: An anthropological perspective, in: Soils and human health, edited by: Brevik, E. C. and Burgess, L. C., Boca Raton, FL, USA, CRC Press, 179-198, 2013.

Hertz, H.: Notes on clay and starch eating among Negroes in a southern urban community, Soc. Forces, 25, 343-344, 1947.

Hippocrates: On airs, waters and places (reprint), Whitefish, MT, USA, Kessinger Publishing, LLC, 2010.

Hooda, P. and Henry, J.: Geophagia and human nutrition, in: Consuming the inedible. Neglected dimensions of food choice, edited by: MacClancy, J., Henry, J. and MacBeth, H., New York, NY, Berghahn Books, 89-98, 2007. 
Horrigan, L., Lawrence, R. S., and Walker, P.: How sustainable agriculture can address the environmental and human health harms of industrial agriculture, Environ. Health Persp., 110, 445-456, 2002.

Hough, R. L.: Soil and human health: an epidemiological review, Eur. J. Soil Sci., 58, 1200-1212, 2007.

Howard, A.: An agricultural testament, London, UK, Oxford University Press, 1940.

Howard, A.: The soil and health: A study of organic agriculture, New York, NY, USA, Devin-Adair Company, 1947.

Hu, Q.-H., Weng, J.-Q., and Wang, J.-S.: Sources of anthropogenic radionuclides in the environment: A review, J. Environ. Radioactiv., 101, 426-437, 2010.

IPCC: Summary for policymakers, in: Climate change 2007: the physical science basis, Contribution of Working Group I to the Fourth Assessment Report of the Intergovernmental Panel on Climate Change, edited by: Solomon, S., Qin, D., Manning, M., Chen, Z., Marquis, M., Averyt, K. B., Tignor, M., and Miller, H. L., Cambridge, UK, Cambridge University Press, 1-18, 2007.

Jamieson, R. C., Gordon, R. J., Sharples, K. E., Stratton, G. W., and Madani, A.: Movement and persistence of fecal bacteria in agricultural soils and subsurface drainage water: A review, Canadian Biosystems Engineering, 44, 1.1-1.9, 2002.

Jenkins, M. B., Bowman, D. D., Fogarty, E. A., and Ghiorse, W. C.: Cryptosporidium parvumoocyst inactivation in three soil types at various temperatures and water potentials, Soil Biol. Biochem., 34, 1101-1109, 2002.

Jones, B.: Animals and medical geology, in: Essentials of Medical Geology, edited by: Selinus, O., Alloway, B., Centeno, J. A., Finkelman, R. B., Fuge, R., Lindh, U., and Smedley, P., Amsterdam, The Netherlands, Elsevier, 513-526, 2005.

Jovic, S., Djordjevic, M., Kulisic, Z., Pavlovic, S., and Radenkovic, B.: Infectivity of Trichinella spiralis larvae in pork buried in the ground, Parasite, (2 Suppl.), S213-S215, 2001.

Kabata-Pendias, A. and Mukherjee, A. B.: Trace elements from soil to human, Berlin, Germany, Springer-Verlag, 2007.

Kalkstein, L. S. and Greene, J. S.: An evaluation of climate/mortality relationships in large U.S. cities and the possible impacts of climate change, Environ. Health Persp., 105, 84-93, 1997.

Kang, Y., Khan, S., and Ma, X.: Climate change impacts on crop yield, crop water productivity, and food security - a review, Prog. Nat. Sci., 19, 1665-1674, 2009.

Kay, A. B.: Overview of "Allergy and allergic diseases: with a view to the future", Brit. Med. Bull., 56, 843-864, 2000.

Kellogg, C. E.: Soil and society, in: Soils and Men: Yearbook of Agriculture 1938, edited by: Knight, H. G., Kellogg, C. E., Barnes, C. P., McCall, M. A., Allin, B. W., Patrick, A. L., Baker, O. E., Enlow, C. R., Bressman, E. N., Munns, E. N., and Hambidge, G., Washington, DC, USA, United States Government Printing Office, 863-886, 1938.

Kerr, J., Boswell, N. A., Bennett, J. B., Allan, F. G., Jaffe, H., Binns, G., Kerr, J. H., Blacklay, O. H., Loney, R. E., Bower, H. E., Lynd, W. S., Brice, H. D., Murphy, J., Chadwick, J. W., Murphy, J. B., Chisholm, J. D., Parkes, M., Davidson, R. B., Platt, J. N., Dickson, W. W., Pollard, L. T., Dwyer, M., Robertson, J. R., English, H., Russell, W. J. A., Fellows, F. M., Thomas, W. E. C., Fulton, J. B., Wraith, F., Gerrard, R. F., and Picton, L. J.: Medical Testament - County Palatine of Chester Local Medical and
Panel Committee, available at: http://journeytoforever.org/farm library/medtest/medtest.html (last access: 16 December 2013), 1939.

Khan, S., Cao, Q., Zheng, Y. M., Huang, Y. Z., and Zhu, Y. G.: Health risks of heavy metals in contaminated soils and food crops irrigated with wastewater in Beijing, China, Environ. Pollut., 152, 686-692, 2008.

Kibble, A. J. and Saunders, P. J.: Contaminated land and the link to health, in: Assessment and reclamation of contaminated land. Issues in environmental science and technology, edited by: Hester, R. E. and Harrison, R. H., Cambridge, UK, Royal Society of Chemistry, 65-84, 2001.

Kirkham, M. B.: Internationalization of soil physics from an American perspective, International Agrophysics, 26, 181-185, 2012.

Klasing, K. C., Goff, J. P., Greger, J. L., King, J. C., Lall, S. P., Lei, X. G., Linn, J. G., Nielsen, F. H., and Spears, J. W.: Mineral Tolerance of Animals, Washington, DC, USA, The National Academies Press, 2005.

Kolpin, D. W., Barbush, J. E., and Gilliom, R. J.: Pesticides in ground water of the United States, 1992-1996, Ground Water, 38, 858-863, 2000.

Lal, R.: Managing soils and ecosystems for mitigating anthropogenic carbon emissions and advancing global food security, BioScience, 60, 708-721, 2010.

Lal, R. and Shukla, M.: Principles of soil physics, New York, NY, USA, Marcel Dekker, 2004.

Laufer, B.: Geophagy, Chicago, IL, USA, Field Museum Press, 1930.

Lechevalier, H. A. and Lechevalier, M. P.: Biology of actinomycetes, Annu. Rev. Microbiol., 21, 71-100, 1967.

Lee, W.-Y., Iannucci-Berger, W., Eitzer, B. D., White, J. C., and Mattina, M. I.: Persistent organic pollutants in the environment: Chlordane residues in compost, J. Environ. Qual., 32, 224-231, 2003.

Leung, A. O. W., Duzgoren-Aydin, N. S., Cheung, K. C., and Wong, M. H.: Heavy metals concentrations of surface dust from e-waste recycling and its human health implications in southeast China, Environ. Sci. Technol., 42, 2674-2680, 2008.

Lohr, V. I. and Pearson-Mins, C. H.: Childhood contact with nature influences adult attitudes and actions towards trees and gardening, in: International Interaction by Design: Bringing People and Plants Together for Health and Well-Being-An International Symposium, edited by: Shoemaker, C. A., Ames, IA, USA, Iowa State Press, 2002.

Loynachan, T. E.: Human disease from introduced and resident soilborne pathogens, in: Soils and human health, edited by: Brevik, E. C. and Burgess, L. C., Boca Raton, FL, USA, CRC Press, 107-136, 2013.

Matricardi, P. M. and Bonini, S.: Mimicking microbial "education" of the immune system: a strategy to revert the epidemic trend of atopy and allergic asthma?, Respir. Res., 1, 129-132, 2000.

Mbila, M.: Soil minerals, organisms, and human health: Medicinal uses of soils and soil materials, in: Soils and human health, edited by: Brevik, E. C. and Burgess, L. C., Boca Raton, FL, USA, CRC Press, 199-213, 2013.

McCarrison, R.: Studies in deficiency disease, London, UK, Hazell, Watson and Viney Ltd., 1921. 
McLeod, M., Aislabie, J., Ryburn, J., and McGill, A.: Regionalizing potential for microbial bypass flow through New Zealand soils, J. Environ. Qual., 37, 1959-1967, 2008.

McMurtrey, J. E. and Robinson, W. O.: Neglected soil constituents that affect plant and animal development, in: Soils and Men: Yearbook of Agriculture 1938, edited by: Knight, H. G., Kel$\operatorname{logg}$, C. E., Barnes, C. P., McCall, M. A., Allin, B. W., Patrick, A. L., Baker, O. E., Enlow, C. R., Bressman, E. N., Munns, E. N., and Hambidge, G., Washington, DC, USA, United States Government Printing Office, 807-829, 1938.

Mills, C. F.: Trace elements in human nutrition and health, Geneva, Switzerland, World Health Organization, 1996.

Morgan, H. and Simms, D. L.: [The Shipham Report] Discussion and conclusions, Sci. Total Environ., 75, 135-143, 1988.

Morgan, R.: Soil, heavy metals, and human health, in Soils and human health, edited by: Brevik, E. C. and Burgess, L. C., Boca Raton, FL, USA, CRC Press, 59-82, 2013.

Nasser, A. M., Huberman, Z., Zilberman, A., and Greenfeld, S.: Die-off and retardation of Cryptosporidium spp. oocyst in loamy soil saturated with secondary effluent, Water Sci. Technol., 3, 253-259, 2003.

NRCS: Soil health awareness, available at: http://www.nrcs.usda. gov/wps/portal/nrcs/main/national/soils/health/, last access: 02 June 2014.

Oliver, M. A.: Soil and human health: a review, Eur. J. Soil Sci., 48, 573-592, 1997.

Parry, M., Rosenzweig, C., and Livermore, M.: Climate change, global food supply, and risk of hunger, Philos. T. Roy. Soc. B, 360, 2125-2138, 2005.

Pepper, I. L.: The soil health: human health nexus, Crit. Rev. Env. Sci. Tec., 43, 2617-2652, 2013.

Pepper, I. L., Gerba, C. P., Newby, D. T., and Rice, C. W.: Soil: a public health threat or savior?, Crit. Rev. Env. Sci. Tec., 39, 416432, 2009.

Pettry, D. E., Reneau Jr., R. B., Shanholtz, M. I., Graham Jr, S. A., and Weston, C. W.: Soil pollution and environmental health, Health Services Reports, 88, 323-327, 1973.

Pimentel, D.: Soil erosion: A food and environmental threat, Environ. Develop. Sustain., 8, 119-137, 2006.

Pimentel, D. and Burgess, M.: Soil erosion threatens food production, Agriculture, 3, 443-463, 2013.

Pohl, H., DeRosa, C., and Holler, J.: Public health assessment for dioxin exposure from soil, Chemosphere, 31, 2437-2454, 1995.

PSNRU: Welcome to the Plant, Soil and Nutrition Research Unit, available at: http://www.ars.usda.gov/main/site_main.htm? modecode=19-07-05-05, (last access: 17 December 2013) 2008.

Pyle, J. A., Warwick, N., Yang, X., Young, P. J., and Zeng, G.: Climate/chemistry feedbacks and biogenic emissions, Philos. T. Roy. Soc. A, 365, 1727-1740, 2007

Queijo, J.: Breakthrough: How the 10 greatest discoveries in medicine saved millions and changed our view of the world, Upper Saddle River, NJ, USA, Pearson Education, Inc., 2010.

Rangaswami, G., and Ethiraj, S.: Antibiotic production by Streptomyces sp. in unamended soil, Phytopathology, 52, 989-992, 1962.

Rayman, M. P.: The importance of selenium to human health, Lancet, 356, 233-241, 2000.

Relf, P. D. and Lohr, V. I.: Human issues in horticulture, HortScience, 38, 984-993, 2003.
Revankar, S. G. and Sutton, D. A.: Melanized fungi in human disease, Clin. Microbiol. Rev., 23, 884-928, 2010.

Richter Jr., D. D., Bacon, A. R., Megan, L. M., Richardson, C. J., Andrews, S. S., West, L., Wills, S., Billings, S., Cambardella, C. A., Cavallaro, N., DeMeester, J. E., Franzluebbers, A. J., Grandy, A. S., Grunwald, S., Gruver, J., Hartshorn, A. S., Janzen, H., Kramer, M. G., Ladha, J. K., Lajtha, K., Liles, G. C., Markewitz, D., Megonigal, P. J., Mermut, A. R., Rasmussen, C., Robinson, D. A., Smith, P., Stiles, C. A., Tate, R. L., Thompson, A., Tugel, A. J., van Es, H., Yaalon, D., and Zobeck, T. M.: Humansoil relations are changing rapidly: proposals from SSSA's crossdivisional Soil Change Working Group, Soil Sci. Soc. Am. J., 75, 2079-2084, doi:10.2136/sssaj2011.0124, 2011.

Robinson, B. H.: E-waste: An assessment of global production and environmental impacts, Sci. Total Environ., 408, 183-191, 2009.

Rodale, J. I.: Pay dirt: Farming and gardening with composts, New York, NY, USA, Devin-Adair Company, 1945.

Rook, G. A. W.: 99th Dahlem conference on infection, inflammation and chronic inflammatory disorders: Darwinian medicine and the "hygiene" or "old friends" hypothesis, Clin. Exp. Immunol., 160, 70-79, 2010.

Ross, C. M. and Donnison, A. M.: Campylobacter jejuni inactivation in New Zealand soils, J. Appl. Microbiol., 101, 1188-1197, 2006.

Rowbotham, T. J.: Preliminary report on the pathogenicity of Legionella pneumophila for freshwater and soil amoebae, J. Clin. Pathol., 33, 1179-1183, 1980.

Roy, M. and McDonald, L. M.: Metal uptake in plants and health risk assessments in metal-contaminated smelter soils, Land Degrad. Develop., doi:10.1002/ldr.2237, 2013.

Sauer, T. J. and Nelson, M. P.: Science, ethics, and the historical roots of our ecological crisis. Was White right?, in: Sustaining soil productivity in response to global climate change: science, policy, and ethics, edited by: Sauer, T. J., Norman, J. M., and Sivakumar, M. V. K., Oxford, UK, John Wiley \& Sons, Inc., 316, 2011.

Sedman, R. M.: The development of applied action levels for soil contact: A scenario for the exposure of humans to soil in a residential setting, Environ. Health Persp., 79, 291-313, 1989.

Selinus, O., Alloway, B., Centeno, J. A., Finkelman, R. B., Fuge, R., Lindh, U., and Smedley, P. (Eds.): Essentials of medical geology, Amsterdam, The Netherlands, Elsevier, 2005.

Senesil, G. S., Baldassarre, G., Senesi, N., and Radina, B.: Trace element inputs into soils by anthropogenic activities and implications for human health, Chemosphere, 39, 343-377, 1999.

Sharratt, B. S. and Lauer, D.: Particulate matter concentration and air quality affected by windblown dust in the Columbia Plateau, J. Environ. Qual., 35, 2011-2016, 2006.

Shigova, W. and Moturi, W.: Geophagia as a risk factor for diarrhea, Journal of Infection in Developing Countries, 3, 94-98, 2009.

Simcox, N. J, Fenske, R. A., Wolz, S. A., Lee, I. C., and Kalman, D. A.: Pesticides in household dust and soil: exposure pathways for children of agricultural families, Environ. Health Persp., 103, 1126-1134, 1995.

Skinner, H. C. W. and Berger, A. R. (Eds.): Geology and health: Closing the gap, Oxford, UK, Oxford University Press, 2003.

Smith, B., Rawlins, B. G., Cordeiro, M., Hutchins, M. G., Tiberindwa, J. V., Sserunjogi, L., and Tomkins, A. M.: The bioaccessibility of essential and potentially toxic elements in tropical 
soils from Mukono District, Uganda, J. Geol. Soc. Lond., 157, 885-891, 2000.

Sorenson, J. R. J., Campbell, I. R., Tepper, L. B., and Lingg, R. D.: Aluminum in the environment and human health, Environ. Health Persp., 8, 3-95, 1974.

Spiegel, H., Sager, M., Oberforster, M., Mechtler, K., Stüger, H. P., and Baumgarten A.: Nutritionally relevant elements in staple foods: influence of arable site versus choice of variety, Environ. Geochem. Health, 31, 549-560, 2009.

Steinnes, E.: Soils and human health, in: Sustaining soil productivity in response to global climate change: science, policy, and ethics, edited by: Sauer, T. J., Norman, J. M., and Sivakumar, M. V. K., Oxford, UK, John Wiley \& Sons, Inc., 79-86, 2011.

Stoll, S.: Larding the lean Earth: Soil and society in nineteenthcentury America, New York, NY, USA, Hill and Wang, 2002.

Strehlow, C. D. and Barltrop, D.: [The Shipham Report] Health studies, Sci. Total Environ., 75, 101-133, 1988.

Sylvia, D. M., Fuhrmann, J. J., Hartel, P. G., and Zuberer, D. A.: Principles and applications of soil microbiology, Upper Saddle River, NJ, USA, Prentice Hall, 1998.

Tabor, J. A., O’Rourke, M. K., Lebowitz, M. D., and Harris, R. B.: Landscape-epidemiological study design to investigate an environmentally based disease, J. Expo. Sci. Env. Epid., 21, 197-211, 2011.

Taylor, M. P., Mackay, A. K., Hudson-Edwards, K. A., and Holz, E.: Soil $\mathrm{Cd}, \mathrm{Cu}, \mathrm{Pb}$ and $\mathrm{Zn}$ contaminants around Mount Isa city, Queensland, Australia: Potential sources and risks to human health, Appl. Geochem., 25, 841-855, 2010.

Thomson, C. D. and Robinson, M. F.: Selenium in human health and disease with emphasis on those aspects peculiar to New Zealand, Am. J. Clin. Nut., 33, 303-323, 1980.

Torkzabana, S., Hassanizadeh, S. M., Schijven, J. F., de Bruin, H. A. M., and de Roda Husman, A. M.: Virus transport in saturated and unsaturated sand columns, Vadose Zone J., 5, 877-885, 2006.

Tu, C., Ma, L. Q., and Bondada, B.: Arsenic accumulation in the hyperaccumulator Chinese brake and its 957 utilization potential for phytoremediation, J. Environ. Qual., 31, 1671-1675, 2002.

Turick, C. E., Knox, A. S., and Kuhne, W. W.: Radioactive elements in soil: interactions, health risks, remediation and monitoring, in Soils and human health, edited by: Brevik, E. C. and Burgess, L. C., Boca Raton, FL, USA, CRC Press, 137-154. 2013.

Ulrich, R. S.: View through a window may influence recovery from surgery, Science, 224, 420-421, 1984.

Underwood, E. J.: Trace elements in human and animal nutrition, New York, NY, USA, Academic Press, Inc., 1956.
Varo, P., Alfthan, G., Ekholm, P., Aro, A., and Koivistoinen, P.: Selenium intake and serum selenium in Finland: effects of soil fertilization with selenium, Am. J. Clin. Nutr., 48, 324-329, 1988.

Vermeer, D. and Frate, D.A.: Geophagia in rural Mississippi: environmental and cultural context and nutritional implications, Am. J. Clin. Nutr., 32, 2129-2135, 1979.

Voisin, A.: Soil, grass, and cancer, New York, NY, USA, Philosophical Library Inc., 1959.

Waldron, H. A.: Occupation health and the archaeologist, Brit. J. Ind. Med., 42, 793-794, 1985.

Walsh, L. M., Sumner, M. E., and Keeney, D. R.: Occurrence and distribution of arsenic in soils and plants, Environ. Health Persp., 19, 67-71, 1977.

Weindorf, D. C., Paulette, L., and Man, T.: In-situ assessment of metal contamination via portable x-ray fluorescence spectroscopy: Zlatna, Romania, Environ. Pollut., 182, 92-100, doi:10.1016/j.envpol.2013.07.008, 2013.

Whicker, J. J., Pinder III, J. E., Breshears, D. D., and Eberhart, C. F.: From dust to dose: Effects of forest disturbance on increase inhalation exposure, Sci. Total Environ., 368, 519-530, 2006.

Wilson, M. J.: Clay mineralogical and related characteristics of geophagic material, J. Chem. Ecol., 29, 1525-1547, 2003.

Wynne, B.: Sheepfarming after Chernobyl: A case study in communicating scientific information, Environment: Science and Policy for Sustainable Development, 31, 10-39, 1989.

Yamada, Y.: Radon exposure and its health effects, J. Health Sci., 49, 417-422, 2003.

Ye, M., Sun, M., Liu, Z., Ni, N., Chen, Y., Gu, C., Kengara, F. O., Li, H., and Jiang, X.: Evaluation of enhanced soil washing process and phytoremediation with maize oil, carboxymethyl-âcyclodextrin, and vetiver grass for the recovery of organochlorine pesticides and heavy metals from a pesticide factory site, J. Environ. Manage., 141, 161-168, 2014.

Young, S.: Evidence for the consumption of the inedible. Who, what, when, where and why?, in: Consuming the inedible. Neglected dimensions of food choice, edited by: MacClancy, J., Henry, J., and MacBeth, H., New York, NY, Berghahn Books, 17-30, 2007.

Young, S., Wilson, M. J., Hillier, S., Delbos, E., Ali, S. M., and Stoltzfus, R. J.: Differences and commonalities in physical, chemical and mineralogical properties of Zanzibari geophagic soils, J. Chem. Ecol., 36, 129-140, 2010.

Zhang, H. and Selim, H. M.: Kinetics of arsenate adsorptiondesorption in soils, Environ. Sci. Technol., 39, 6101-6108, 2005.

Zhuang, P., McBride, M. B., Xia, H., Li, N., and Li, Z.: Health risk from heavy metals via consumption of food crops in the vicinity of Dabaoshan mine, South China, Sci. Total Environ., 407, 15511561, 2009. 